\title{
Individual selection in a genetic test with 43 advanced progenies of camu-camu Myrciaria dubia Kunth (McVaugh) in floodable plot near lquitos, Peruvian Amazon
}

\author{
Mario Pinedo-Panduro ${ }^{1, *}(\mathbb{D})$; Edvan Alves-Chagas ${ }^{2}$ (D); Elvis Paredes-Davila ${ }^{1} \mathbb{D}^{\mathbb{D}}$; Carlos \\ Abanto-Rodriguez ${ }^{1} \mathbb{D}^{\mathbb{D}}$; Ricardo Bardales-Lozano ${ }^{1} \mathbb{D}^{\text {; }}$ Pollyana Cardoso-Chagas ${ }^{3}$ (D); ; \\ Valdinar Ferreira Melo ${ }^{3}$; Dennis Del Castillo-Torres ${ }^{1} \mathbb{D}^{\mathbb{D}}$; Nadia Masaya Panduro- \\ Tenazoa $^{4}$ (D) \\ 1 Instituto de Investigaciones de la Amazonía Peruana (IIAP), Avnda. Abelardo Quiñones km 2.5 lquitos, Peru. \\ 2 Empresa Brasileira de Pesquisa Agropecuária - Roraima, EMBRAPA, Rodovia BR 174, Km 8, Distrito Industrial, Boa \\ Vista, Roraima, Brazil. \\ 3 Universidade Federal de Roraima (UFRR), Postgraduate Program in Agronomy - POSAGRO, Boa Vista, Brazil. \\ 4 Universidad Nacional Intercultural de la Amazonía (UNIA) Carretera a San José km. 0.63, Pucallpa, Peru.
}

Received March 11, 2020. Accepted June 25, 2020.

\begin{abstract}
The research summarized and validated the individual selection of camu-camu (Myrciaria dubia (Kunth) McVaugh) plants. 43 progenies, previously selected in genetic tests and fields of producers of flood areas, were evaluated. Each progeny was installed in a row of 10 half-sister plants, with a space of $3 \times 2$ $\mathrm{m}$. Using the SELEGEN (Reml / Blup) Model 63 program, four crops were analyzed, and individuals were selected for each of the 16 descriptors evaluated. For fruit yield, the Tipishca-Río Tigre population stood out, occupying 5 of the first 10 places. The individuals TT0725-4 (Tigre-Tipishca) turned out to be a natural recombinant for fruit yield / weight. And individual 64-8 turned out to be triple recombinant (yield / fruit weight / ascorbic acid). The descriptors with the highest genetic control with $r \geq 0.30$ were: average fruit weight, brix degrees, plant height, number of basal branches and petiole length. The criteria of similarity of the morphological markers with the fruit yield are proposed as predictive indexes of productivity. The plant height at two years of age was the most important.
\end{abstract}

Keywords: amazon rainforest; fruit food; genetic evaluation; genetic selection; tree breeding.

\section{Introduction}

In recent years, camu-camu agronomic and genetic research has been highly active. Different aspects have been covered such as fertilization (Abanto et al., 2019; Ferreira et al., 2019; Panduro et al., 2016 and Abanto et al., 2015a,b), the control of the fruit weevil (Conotrachelus dubiae), defoliation (Pinedo et al., 2017; Durand et al., 2017), pruning and planting density (Durand et al., 2017), fruit retention (Pinedo et al., 2018), carbon sequestration (Diaz et al., 2015) and commercialization (Braga et al., 2018). Progenies and individuals with low levels of incidence of fruit weevil and jumping louse (Tuthillia cognata) were identified, which could mean tolerance or resistance to attack by these important pests (Pinedo et al., 2017).

One of the limitations of camu-camu cultivation is low productivity. Among the causes is the low genetic quality of the seed that has been used in the productive plots. The progress in the pre-improvement works (collection, evaluation, selection) of the species is significant, mainly in Peru (Pinedo et al., 2017) and Brazil (Bardales et al., 2016) with a wide studied sample for four decades. However, we appreciate, as an information gap, the lack of long-term analysis that integrates fragmented progress over time and geographic coverage. So that we can have

\footnotetext{
Cite this article:

Pinedo-Panduro, M.; Alves-Chagas, E.; Paredes-Davila, E.; Abanto-Rodríguez, C.; Bardales-Lozano, R.; Cardoso-Chagas P.; Melo, V.F.; Del Castillo-Torres, D.; Panduro-Tenazoa, N.M. 2020. Individual selection in a genetic test with 43 advanced progenies of camu-camu Myrciaria dubia Kunth (McVaugh) in floodable plot near lquitos, Peruvian Amazon. Scientia Agropecuaria 11(3): 345-355
} 
identified and accessible, reliable select material as a product of various measurements (4 to 10 ) or harvests.

The genetic selection of superior matrices, especially in fruit trees, has allowed significant progress in favor of their sustainable use. For example, the evaluation of naranjilla (Solanum quitoense Lam.) progenies from interspecific crosses (Silva et al., 2016). Likewise, the selection of hybrids with high performance and resistance to Moniliasis (Solis et al., 2015). In non-arboreal fruit trees such as mulberry (Rubus glaucus Bentham), promising genotypes were selected for the size and color of the fruit, the total content of soluble solids and other morphological markers (Sánchez et al., 2020).

About camu-camu, INIA-Iquitos, during 1986-1988, collected 39 populations in the Ucayali, Amazonas, Marañón and Napo rivers, and evaluated them for 15 years. Ten plants stood out for fruit yield, in floodplains of black water (island of Muyuy) and 10 in soils of highland, with yields between 6 and $25 \mathrm{t} \mathrm{ha}^{-1}$ at 11 years of age (Mendoza et al., 1989).

In IIAP, in the years 2005 and 2006, 715 precocious plants were pre-selected. During 2007, 2008 and 2009, progenies and individuals were evaluated and selected according to vegetative parameters and highlighted the progenies 21 and 222. This analysis showed that early selection by vegetative parameters is important but not definitive information for the selection of higher plants according to fruit yield (Pinedo and Paredes, 2011).

In the last 15 years, basic collections, and genetic tests of camu-camu are being evaluated at the San Miguel Experimental Center (CESM-IIAP), which has allowed the increase of the genetic base with top material. Higher plants have been identified in terms of fruit yield, vitamin C content, pest tolerance and other agronomic characteristics. In the CESM-IIAP, the sixth evaluation of vegetative and reproductive parameters of 37 clones was carried out, which were evaluated consecutively at $5,9,23,35,46$ and 58 months after planting. At 5 years of age, significant differences were found between clones with respect to canopy diameter (FC $=10.44$, Sig $=0.00$ ) and number of flowers $(F c=3.46$, Sig $=0.019)$. No significant differences were found regarding the parameters basal stem diameter $(F c=1.773$, Sig $=$ $0.157)$, total basal stem diameter $(\mathrm{Fc}=$ 0.368 , Sig $=0.76)$, plant height $(F c=2.088$, Sig $=0.106)$, number of basal branches ( $F c=$ 0.163 , Sig $=0.921$ ) and number of fruits (Fc $=0.76$, Sig $=0.55$ ) (Pinedo and Paredes, 2011). Smíd et al., (2017) confirms the high genetic diversity between natural and cultivated populations using molecular markers and the great potential for genetic improvement work.

We present the evaluations in an advanced genetic test of 43 progenies, installed in 2010 , at CESM. The evaluation was carried for four years, to select progenies and individuals in accordance with the camu-camu genetic improvement plan (Pinedo et al., 2004). These results will provide a reference on the productivity and will serve as a basis for subsequent productivity analysis and consistent selection.

\section{Materials and methods}

This work was installed in 2010 and carried out in the Experimental Center "San Miguel" -CESM-IIAP, located on the left bank of the Amazon River, $10 \mathrm{~km}$ upstream from the city of lquitos, between the coordinates $3^{\circ} 40^{\circ}$ and $3^{\circ} 45^{\prime}$ South Latitude and $73^{\circ} 10^{\circ}$ and $73^{\circ}$ $11^{\prime}$ West Longitude. The place is floodable located on the banks of the Amazon river, locally known as restinga, classified globally as a wetland (ecosystem permanently or seasonally flooded), globally or as a varzea (floodplains are known to be arable land alongside rivers) in Brazil; with an average temperature of $26{ }^{\circ} \mathrm{C}$, rainfall of 2911.7 $\mathrm{mm} /$ year (Pinedo et al., 2018). 43 progenies were installed on a plot of $2580 \mathrm{~m}^{2}$. in randomized form, with 10 repetitions or half-sisters, experimental units made up of a single plant and distance of $3 \times 2$ meters. The progenies come from CESM-IIAP-Iquitos, INIA-Loreto and IIAP-Pucallpa. The matrices were chosen for their high yields and stability in the production of fruit during several years of study.

\section{Independent variables evaluated}

The descriptors evaluated and analyzed were:

Plant height, number of basal branches (at a maximum height of $50 \mathrm{~cm}$ above the ground and at least $2 \mathrm{~cm}$ in diameter), number of terminal branches, percentage of fruits attacked by fruit weevil (Conotrachelus dubiae), number of fruits/plant (state 5 to 8 ), fruit weight (g) (sample of 20 fruits/plant), fruit yield ( $g$ ) (number of fruits $x$ average weight of the fruit), potential for hydrogen radicals $(\mathrm{pH})$ (on a $30 \mathrm{ml}$ sample of fresh pulp), fruit, pulp and seed weight (average mass from 25 measurements), petiole length, limbo length, limbo width (expressed in millimeters), basal stem diameter (under the first branch, precision to the decimilimeter). 


\section{Statistical design}

The completely randomized design was applied at progeny level and not by individuals, with the same number of repetitions and one plant per experimental unit; that is, a total of 43 families were evaluated, with ten repetitions each, totaling 430 individuals. For the statistical analyzes the SPSS Version 20 and Selegen-Reml/Blup basic model 63 programs were used. For the selection of superior genotypes through a multiannual analysis, model 63 was applied: basic repetitiveness model without delineation (Carias et al., 2016). The statistical model responds to the expression: $y=X m+W p+e$; where " $y$ " is the vector of each of the data " $m$ " vector of the measurement effects (assumed as fixed) added to the general mean " $p$ " vector of the permanent effects (genotypic effects+environmental effects) assumed as random and " $e$ " vector of errors or residuals (random). The capital letters represent the incidence matrices for the afore mentioned effects.

The results obtained were expressed in (a) components of variance (b) efficiency of use of the number of measures and (c) genotypic values with the selection of individuals or progeny (Tables 1 and 2).

The variance components are Vfp: Permanent phenotypic variation between plants (genotypic + permanent environmental from one crop to another); Vet: Variation of temporary environment; Vf: Individual phenotypic variance $r=h 2$ : individual repetitiveness $\mathrm{rm}$ : repetitiveness of the average of $m$ crops o repeated measures and Acm: precision of the selection based on the average of $\mathrm{m}$ crops or repeated measures.

The efficiency of using " $m$ " measures (annual evaluations, which in this case are three) was given by three parameters: determination (coefficient), precision (obtained with $m$ repeated measures) and efficiency (of $\mathrm{m}$ measures compared to only one). Accuracy in the range of 0.10 to 0.39 is considered low, values of 0.45 to 0.63 are considered medium or moderate values and values greater than 0.71 are high (Resende, 2002).

The selection of individuals was based on the value of " $\mathrm{fp}$ " is permanent phenotypic effect and " $u+f p$ " is permanent phenotypic value, genetic gain, and the new mean as the basis for selection in order of decreasing merit.

The genotypic values of each plant were estimated by: $\hat{g}=M G+\beta_{p}\left(M P_{i}-M G\right)$ in which: $\beta_{p}=[m \dot{p} /(1+(m-1) \dot{p})]$ is the coefficient of determination of the permanent phenotypic value or repetitiveness of the mean of M: 4 measurements in the individual; $\dot{p}$ : estimate of individual repetitiveness; $M G$ : general average of the plants in several measurements; MPi: general mean of the plant $i$ in the various measurements.

MP is the sum of these variance components, according to Resende (2002), the repetitiveness classification is: high (greater than 0.60), medium (between 0.30 to 0.60 ) and low (less than 0.30). The same author classifies heritability in the restricted sense as low (between 0.01 to 0.015 ), medium or moderate between $(0.15$ to 0.50$)$ and high (greater than 0.50).

\section{Results and discussion}

Below we present the results and discussions for the period 2010-2017 in 43 progenies (430 plants) of the plot under study. These results are grouped into 4 sections: fruit yield, repetitivity analysis (vegetative, reproductive, and chemical), correlations, and selections.

\section{Fruit yield}

Figure 1 shows a yield range of 1.6 to 2.4 kg.pl-1 of fresh fruit for the top ten individuals among 43 camu-camu progenies evaluated after 4 years of planting in the flood area of the trial under evaluation. It corresponds to the second year of production.

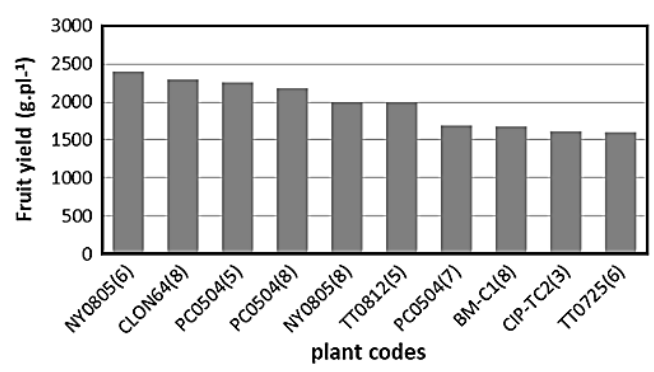

Figure 1. Fruit yield of 10 best individuals 4 years after planting.

Legend-Plants origin (River-Lake or Farmer-River): NY (Napo-Yuracyacu), CLON64 (Putumayo-Cedro), PC (Putumayo-Cedro), TT (Tigre-Tipishca), BM (Bernardo Mahua-Ucayali), CIP (Tito Caballero-Ucayali).

The yield range of 1.6 to $2.4 \mathrm{~kg} \mathrm{plant}^{-1}$, for the top ten individuals among 43 progeny, shown in Figure 1, is within the expected ranges for maximum production plants.

In Figure 2, the yield curve from the third to the sixth year after planting is presented. In the third year, the harvest was very small, with an average of $10 \mathrm{~g}$ of fruit per plant, which is related to the low percentage of plants that began to fructify, which reached only $10 \%$ of the total plants evaluated. In this regard Pinedo et al. (2017), found that said percentage, also in the third year, reached $25 \%$. Figure 4 shows that fruiting begins at the third year of planting with $10 \%$ of the plants. 
Table 1

Repetitivity analysis of four harvests for "average fruit weight" of 43 camu-camu progenies

\begin{tabular}{|c|c|c|c|c|c|}
\hline \multicolumn{6}{|c|}{$\begin{array}{l}\text { SELEGEN Reml/Blup Computerized Statistical System for Genetic Selection. Mixed Linear Model } 63 \\
\text { Number of variables } 1 . \text { Variable analyzed: "average fruit weight" without zeros } \\
\text { Standard Deviation }=1383.47\end{array}$} \\
\hline \multicolumn{6}{|c|}{ Variance Components (Individual REML) } \\
\hline \multicolumn{6}{|c|}{$\begin{array}{l}r=0.303168 \pm 0.0577 \text { (individual repetition) } \\
r m=0.635071 \text { (repetitiveness of the average of } m \text { crops or repeated measurements) } \\
A c m=0.796914 \text { (Selection accuracy based on the average of } m \text { harvests) } \\
\text { General mean }=7.641575\end{array}$} \\
\hline \multicolumn{6}{|c|}{ Efficiency of the use of $m$ ( 4 harvests) for "average fruit weight" } \\
\hline M & \multicolumn{2}{|c|}{ Determination } & Precis & \multicolumn{2}{|c|}{ Efficiency } \\
\hline 1 & \multicolumn{2}{|c|}{0.303168} & 0.550 & \multicolumn{2}{|c|}{1.000000} \\
\hline 4 & \multicolumn{2}{|c|}{0.635071} & 0.796 & \multicolumn{2}{|c|}{1.447337} \\
\hline 10 & \multicolumn{2}{|c|}{0.813107} & 0.901 & \multicolumn{2}{|c|}{1.637693} \\
\hline \multicolumn{6}{|c|}{$\begin{array}{l}\text { Components of media (BLUP Individual). Individual selection } \\
\text { Ten (10) best individual plants according to average fruit weight }\end{array}$} \\
\hline & Individual & $\mathrm{Fp}$ & $u+f p$ & Gain & New media \\
\hline 1 & Clon64-9 & 2.4871 & 10.1287 & 2.4871 & 10.1287 \\
\hline 2 & TT0725-4 & 1.9021 & 9.5436 & 2.1946 & 9.8362 \\
\hline 3 & Clon64-8 & 1.8454 & 9.4870 & 2.0782 & 9.7198 \\
\hline 4 & Clon61-3 & 1.6248 & 9.2663 & 1.9648 & 9.6064 \\
\hline 5 & $141001-7$ & 1.4970 & 9.1386 & 1.8713 & 9.5129 \\
\hline 6 & Pc0504-3 & 1.4302 & 9.0718 & 1.7978 & 9.4393 \\
\hline 7 & $150714-8$ & 1.3342 & 8.9758 & 1.7315 & 9.3731 \\
\hline 8 & I-3 (2) & 1.2618 & 8.9034 & 1.6728 & 9.3144 \\
\hline 9 & Clon64-10 & 1.2541 & 8.8957 & 1.6263 & 9.2679 \\
\hline 10 & TT0725-10 & 1.2355 & 8.8770 & 1.5872 & 9.2288 \\
\hline
\end{tabular}

The mentioned alternance is attributed to adverse environmental factors, which may be related to the presence of pests and the minimization of the development of fruitful branches. It is worth mentioning that in the present study, it was preferred not to apply agronomic improvement techniques to favor genetic expression. In the case of the clones evaluated by Pinedo et al. (2017), the trend in terms of long-term fruit yield was similar. Therefore, stake propagated plants were not found to have higher yields than sexual propagated plants. Even if Mathews et al. (2016) for camu-camu in the first 3 years of development, they found superior performance of plants propagated by cuttings compared to plants propagated by sexual seeds.

Almeida (2014) evaluated the initial development of the selected plants for their high content of ascorbic acid $(\geq 3000 \mathrm{mg} / 100 \mathrm{~g})$. Depending on growth and earliness (18 months from sowing), four individuals from the Uatuma River population were recommended. However, it was evidenced that those plants with high vegetative values, during the first three years, did not have high levels of fruit yield. This contradiction left doubts about the applicability of early vegetative parameters (basal stem diameter, plant height, number of basal shoots) for indirect predictive selection of fruit productivity. Sánchez (2020), when evaluating for 8 years the same material as in this study
(NYO805, NYO518, TTO725, CLON52 and 151910), found a high yield of fruit and ascorbic acid, which demonstrated the genetic gain of the individual selection in a different geographical area (Pucallpa).

In Figure 2 the average trend of fruit yield from the third to the sixth year after planting is presented. In the third year the harvest was very small, around $10 \mathrm{~g}$ of fruit plant ${ }^{-1}$. This, due to the low percentage of plants that began to fructify $(10 \%$ of the total plants evaluated).

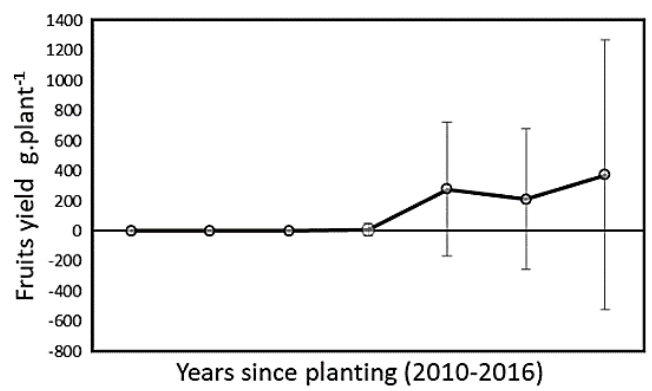

Figure 2. Average yield of camu-camu fruit (g plant-1) in 43 progenies.

It can be seen in Figure 3, that the average weight of the fruit increases slightly with the age of the plant in the first three years of harvest, a trend that apparently changes towards lower levels in the fourth year of harvest. The range is wide between 2 and $14 \mathrm{~g}$ and the average remain at the usual level of $8 \mathrm{~g}$ (Pinedo et al., 2004). 


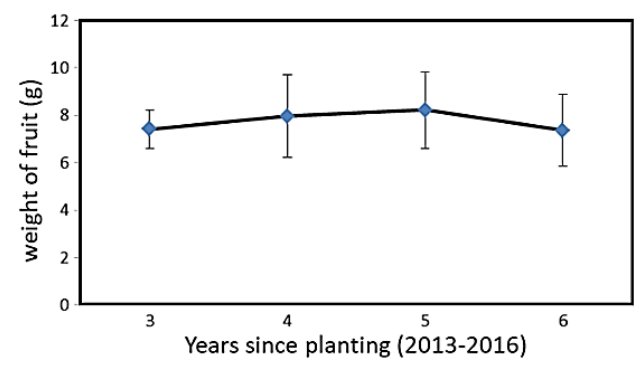

Figure 3. Average weight of fruit (g) in 43 camu-camu progenies.

Figure 4 shows the percentage of plants that begin fruiting during the 4 years of evaluation. Said percentage reached $10 \%$ of plants with fruit, 3 years after planting. The large increase registered in the fourth year (64\%) contrasts with the reduction presented in the last two years. Alternance, that is common under low input conditions in flood areas such as the one studied (Iman, 2000).

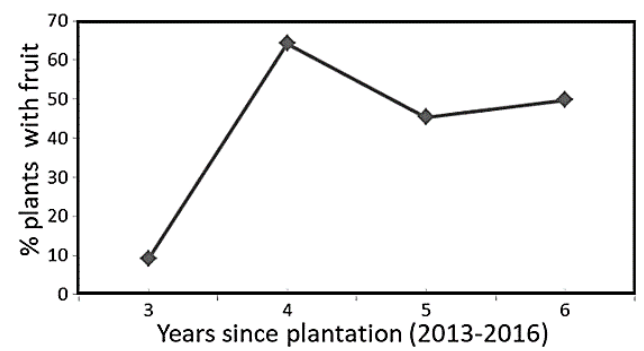

Figure 4. Beginning of fruiting in 43 progenies of camucamu.

\section{Repetitivity analysis}

In Table 1, the repetitivity analysis for the average fruit weight shows a coefficient $r$ that reaches relatively high levels in the fourth harvest, with a general average (7.64) that approximates frequent values in basic genetic material. As you can see, the coefficient improves with the repetition of measurements until reaching the value of $\mathrm{rm}=$ 0.63 in the fourth measurement or year, precision of 0.797 and efficiency of 1.4473 . The order of merit for this descriptor places Clone 64-9 first with $10.13 \mathrm{~g}$ exceeding the value of the ideotype.

Regarding the average weight of the fruit, the coefficient $r$ reached relatively high levels of $\mathrm{rm}=0.635$ in the fourth harvest, precision of 0.797 and efficiency of 1.447 . The order of merit for this descriptor places the individual Clone64-9 first with $10.13 \mathrm{~g}$ that slightly exceeds the value of the ideotype established in the Genetic Improvement Plan (Pinedo et al., 2004). For this variable, Pinedo et al. (2014) found with 3 harvests an $r=0.083$ for the initial material, which in the fourth year reached an $r m=0.268$. Explainable by the greater progress in the selection of the majority of the $\mathbf{4 3}$ descendants evaluated. However, in the case of the 37 clones evaluated, Pinedo et al. (2017) calculated for the average weight of the fruit, a remarkable value of $r=0.690$, which in the fourth year reached an extremely high value of $\mathrm{rm}=$ 0.899 . This allowed a precision of 0.948 . In this case, the improved mean reached a value similar to this test of 43 offspring of $10.041 \mathrm{~g}$. When studying another tropical fruit such as Solanum quitoense (Morillo et al., 2019) they discovered that the weight of the fruit was also one of the most representative variables due to its influence on intraspecific variability and its potential for the selection of higher plants.

The results of the repetitivity analysis for fruit yield in Table 2 show as a result a value of $r=0.189$ (intermediate), the same that in the fourth harvest reached $\mathrm{rm}=0.48$ with a precision of $\mathrm{Acm}=0.694$. In the individual selection, the TT population (Tigre-Tipishca) occupies the first three places and the TT0725 individual stands out with three halfsisters present in the merit table.

For 16 analyzed markers, Table 3 shows the repetitivity, precision and efficiency coefficients, where the descriptor: plant height, with $r=0.44$, is notable for greater genetic control. The same that in the fourth year it reached a value of $\mathrm{rm}=0.611$ and that in the tenth year it would reach $\mathrm{r} 10=0.887$. Another important descriptor for indirect selection is petiole length, which reached $\mathrm{rm}=$ 0.475 .

The results for fruit yield are shown in Table 3 , which reach an intermediate level $(r=$ 0.19 ), and in the fourth harvest it increases to $\mathrm{rm}=0.48$ with a selective precision of $\mathrm{Acm}=0.69$. Oliva et al. (2014) also with camu-camu ecotypes from the Peruvian Amazon, found similar values to those of the present study. With four harvests of 28 provenances and 770 plants, they found an individual repetitivity for the fruit yield of $r=0.19$ that in the fourth harvest increased to $\mathrm{rm}=0.49$ with a selective precision of $\mathrm{Acm}=$ 0.70 . According to these authors, it can be inferred that the heritability for fruit yield is considered moderate. In this regard, Resende (2002) indicated that the estimation of repetitivity is important, because it imposes an upper limit on the value of heritability in a broad sense.

In the case of the fruit yield of 37 camu-camu clones, Pinedo et al. (2017) found a comparatively lower value of $r=0.117$ than in the fifth harvest reached $\mathrm{rm}=0.398$ with an accuracy of $63 \%$. This inferiority is also attributed to the lower advance in selective terms of said marker. 
Table 2

Repetitivity analysis of four harvests for "fruit yield" of 43 camu-camu

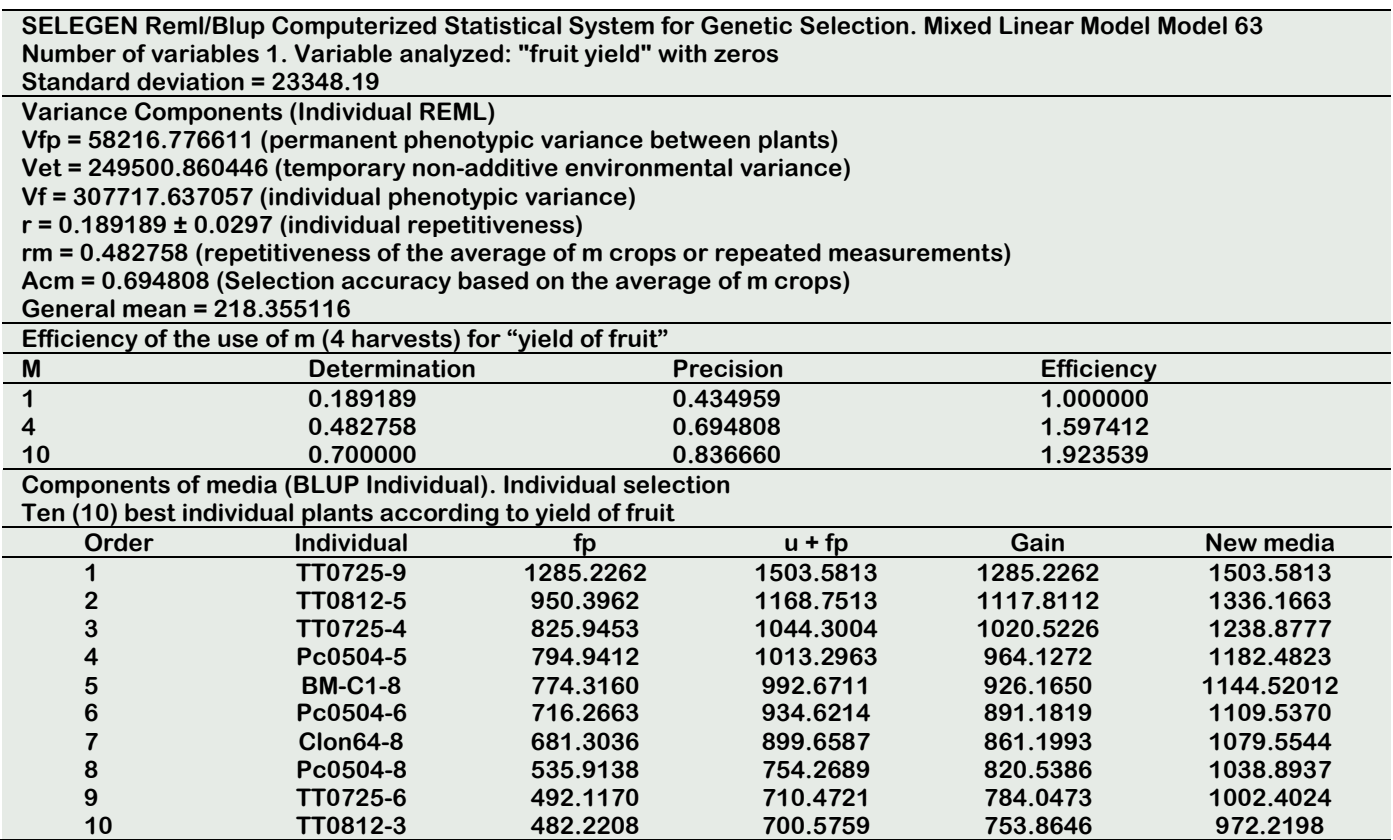

Lejend-Plants Origin: TT(Tigre-Tipishca), Pc(Putumayo-Coto), BM-C(Bernardo Mahua-Ucayali), Clon64(Putumayo-Cedro).

Oliva and Chura (2010), also calculated that for a precision of $77 \%$ in the selection with a determination of $59 \%, 6$ harvests must be evaluated. Regarding our results for the 43 advanced progenies, at 6 years an accuracy of $76.37 \%$ would be reached with a determination of $58.33 \%$ (Table 3 ), which is close to the projection of the mentioned authors.

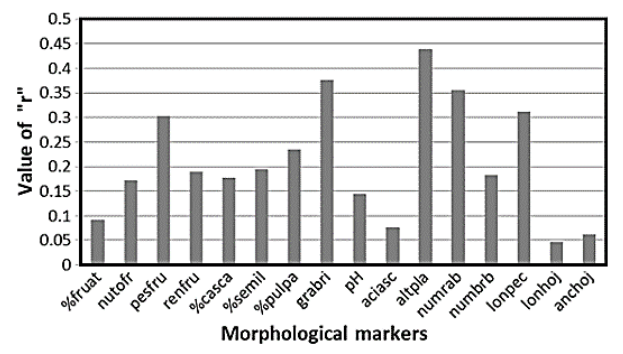

Figure 5. Repetitivity indexes for 16 morphological markers in 43 camu-camu progenies.

Lejend: \%fruat: \% attacked fruits, nutofr: total number of fruits, pesfru: average fruit weight; renfru: fruit yield, \%casca: \%fruit peel, \%semil: \%seed, \%pulpa: \%pulp, grabri: brix degree; $\mathrm{pH}$ : $\mathrm{pH}$, aciasc: ascorbic acid content, altpla: plant heigh, numrab: number of basal branches, numbrb: number of basal shoots, lonpec: length of petiole, lonhoj: leaf length, anchoj: leaf width.

In Figure 5, five markers of greater genetic control are shown, of which the most predictive for the possibility of evaluating them in the short term are: plant height and petiole length.

\section{Correlations}

Table 4 shows the interrelationships between fruit yield versus vegetative markers of higher predictive capacity and more easily measurable. These results in combination with the repetitivity or heritability indexes will allow priority descriptors to be chosen for the selection. For example, the significant negative correlation between "petiole length" and "leaf width" with yield. A descriptor that should also be considered is "plant height" which also showed a significant correlation with fruit yield. For later years, no correlation was obtained between these two variables, apparently with the growth and development of the plant, which weakens the relationship. In the case of plant height, the correlation was optimal two years after planting. Therefore, attention should be paid to the age when the correlation is significant to obtain more reliable results.

In Table 4 we find a significant correlation between the height of the plant and the yield in the first harvest (2013) $r^{2}=0.316^{*}$ (Table 4) but in the following years $(2014,2015$ and 2016) the correlation was of a lower level and turned negative. This trend is probably due to the development of the plant architecture as time passes. Therefore, this correlation presents an opportunity to consider that it would be 2 years after planting. Other researchers also found a significant correlation between these two descriptors for 5 clones in the case of Pinedo et al. (2011) with $r^{2}=0.142^{*}$ and highly significant between plants of different ages and locations. Interestingly, the significant negative correlation 
between petiole length and leaf width with productivity in 2016, with values of $r^{2}=$ $0.152^{*}$ and $r^{2}=-0.150^{*}$ respectively. Analyzing the consistency of these correlations of the parameters and yields of the leaves, we can count on Pinedo et al. (2011) who found a relatively high (but positive) value of $r^{2}=$ 0.371. Pinedo et al. (2017) with a high value of $r^{2}=0.521^{\star \star}$ evidenced another important relationship between petiole length with pulp ascorbic acid content.

The leaf width and leaf length correlations with the ascorbic acid content showed significant values of $r^{2}=0.204^{*}$ and $r^{2}=0.212^{*}$, (Table 4), so it is important to pay attention to these parameters in future evaluations.

A similarity analysis was applied among the 20 highest-yielding plants with the best according to the 16 markers, in order to corroborate the correlation analyzes complemented with those of repetitivity or heritability. This similarity analysis will allow us to glimpse the validity of an indirect and early selection through vegetative characteristics.

Indirect selection of superior camu-camu genotypes using vegetative markers that could be evaluated early, along with calculations of heritability, repetitivity, and correlation with traits of economic interest, may be feasible. Maia et al. (2016), allude to this strategy and propose for "casho" (Anacardium occidentale L.) a system of intensive early selection, based on early descriptors and high heritability. Estimating the repetitivity in the selection of genetically superior trees can provide an improvement in the use of resources, a greater precision in the evaluation and less time in obtaining new cultivars due to the shorter selection cycle. The analysis of the correlations between the morphological markers and the heritability indexes are important for the precision of the superior plant selections. In this sense, Pires et al. (2017) present an integrated method to evaluate selection indices in eucalyptus where correlation analysis is applied, multivariate and its interaction with heritability.

The present study showed us that the markers with the highest genetic control capabilities that are equal to or greater than $r=0.30$ are the average fruit weight, degrees Brix, plant height, number of basal branches and petiole length. Of these, vegetative descriptors are preferable because of their predictive ability before fruiting. So, plant height and petiole length would be the applicable values for an indirect and early selection.

Table 3

Summary of repetitivity analysis for 43 camu-camu progenies

\begin{tabular}{|c|c|c|c|c|c|c|c|c|}
\hline Marker & m & zeros & $r$ & $\mathrm{Rm}$ & Precision & Eficciency & $\underline{x}$ & $r 10$ \\
\hline \%fruat & 4 & No & 0.013 & 0.051 & 0.227 & 1.960 & 30.044 & 0.120 \\
\hline Nutofr & 4 & $\mathrm{Si}$ & 0.172 & 0.454 & 0.674 & 1.624 & 35.243 & 0.822 \\
\hline Pesfru & 4 & No & 0.303 & 0.635 & 0.797 & 1.447 & 7.641 & 0.813 \\
\hline Renfru & 4 & $\mathrm{Si}$ & 0.189 & 0.483 & 0.695 & 1.597 & $\begin{array}{c}217.35 \\
5\end{array}$ & 0.700 \\
\hline$\%$ casca & 3 & Si & 0.178 & 0.395 & 0.628 & 1.487 & 6.502 & 0.685 \\
\hline \%semil & 3 & Si & 0.195 & 0.422 & 0.649 & 1.468 & 6.963 & 0.708 \\
\hline \%pulpa & 3 & Si & 0.235 & 0.480 & 0.693 & 1.428 & 21.036 & 0.754 \\
\hline Grabri & 2 & No & 0.377 & 0.547 & 0.740 & 1.205 & 5.623 & 0.858 \\
\hline $\mathrm{pH}$ & 2 & $\mathrm{Si}$ & 0.145 & 0.254 & 0.504 & 1.321 & 0.398 & 0.630 \\
\hline Aciasc & 2 & No & 0.077 & 0.142 & 0.377 & 1.363 & $\begin{array}{c}1708.0 \\
0\end{array}$ & 0.463 \\
\hline Altpla & 2 & Si & 0.440 & 0.611 & 0.782 & 1.178 & 2.167 & 0.887 \\
\hline Numrab & 2 & $\mathrm{Si}$ & 0.356 & 0.525 & 0.725 & 1.214 & 1.980 & 0.847 \\
\hline Numbrb & 2 & No & 0.183 & 0.310 & 0.556 & 1.300 & 1.938 & 0.691 \\
\hline Lonpec & 2 & No & 0.311 & 0.475 & 0.689 & 1.235 & 5.354 & 0.819 \\
\hline Lonhoj & 2 & No & 0.046 & 0.088 & 0.296 & 1.383 & 68.152 & 0.324 \\
\hline Anchoj & 2 & No & 0.062 & 0.116 & 0.341 & 1.372 & 29.126 & 0.397 \\
\hline
\end{tabular}

Lejend: \%fruat: \% attacked fruits, nutofr: total number of fruits, pesfru: average fruit weight; renfru: fruit yield, \%casca: \%fruit peel, \%semil: \%seed, \%pulpa: \%pulp, grabri: brix degree; $\mathrm{pH}: \mathrm{pH}$, aciasc: ascorbic acid content, altpla: plant heigh, numrab: number of basal branches, numbrb: number of basal shoots, lonpec: length of petiole, lonhoj: leaf length, anchoj: leaf width.

Table 4

Important and statistically significant correlations in genetic testing of $\mathbf{4 3}$ camu-camu progenies

\begin{tabular}{llllll}
\hline Descriptor & Ionpec & nutofr & pesfru & Pesfru & aciasc \\
\hline Altpla & $0.165^{\star \star}$ & $0.164^{\star}$ & $0.124^{\star}$ & $0.201^{\star \star}$ & $0.316^{\star}$ \\
Diabas & $0.183^{\star *}$ & & $0.163^{\star *}$ & $0.163^{\star}$ & \\
Numrab & $0.137^{\star \star}$ & & & $0.174^{\star}$ & \\
Numrat & $0.194^{\star \star}$ & & & $0.170^{\star}$ & $0.204^{\star}$ \\
Anchoj & $0.237^{\star *}$ & $0.191^{*}$ & & $0.212^{\star}$ \\
Lonhoj & & & & $0.241^{\star}$ \\
Renfru & $-0.152^{\star}$ & 0.970 & $0.301^{\star *}$ & & \\
\hline
\end{tabular}

Pearson coefficient significance $\left({ }^{*} p=0.95 ;{ }^{* \star} p=0.99\right)$.
Legend: lonpec: length of petiole, nutofr: total number of fruits, pesfru: average fruit weight. aciasc: ascorbic acid content, altpla: plant heigh, diabas: basal diameter, numrab: number of basal branches, numrat: number of terminal branches, anchoj: leaf width, lonhoj: leaf length, renfru: yield fruit. 
Matias et al. (2016) studied the relationship between the traits of 28 peach cultivars and their direct and indirect effects on the content of ascorbic acid and carotenoids. The yellow color of the pulp was found to have the potential for indirect selection for carotenoid content. In contrast, Quijano (2020), found many polymorphic bands in samples of Pouteria lúcuma collected in northern Peru, but with low genetic differentiation between the areas of origin of the samples.

Among the selections for 16 morphological markers, we consider that the fruit yield is the most important for its economic value. We could select reliable genetic material for each marker, which we can classify according to its use in: a) Of direct interest and utility, such as fruit yield, total number of fruits, ascorbic acid content, average fruit weight, $\%$ of peel, $\%$ seed and $\%$ pulp. This taking into account that in recent years the shell and the seed have also been products with demand in the market for dehydrated products and b) Of indirect interest due to their probable relationship or interdependence that they may have with the descriptors of group a. There, the remaining 9 descriptors are considered.

On correlations, repetitivity and degree of similarity between the descriptors, we can deepen the analysis to identify useful tools for selecting superior genotypes.

The plant height descriptor for having a significant correlation with fruit yield, $\left(r^{2}=\right.$ $0.316 *$ ) consistent with high levels of similarity repetitivity $(s=0.65)(r=0.44)$ may be the best indicator that allows the indirect selection and predictive value in the first months of plant age. Discrimination due to plant height can be favorably carried out in the first year of planting. Due to the similarity with the yield $(s=0.70)$ the shell percentage, also shows a highly significant and negative relationship of $r^{2}=-0.183^{\star *}$. However, to apply this predictor we would have to wait for the first harvest. The very low value of the heritability of ascorbic acid $(r=0.08)$ is already known (Pinedo, 2013). But there is a significant correlation with performance $\left(r^{2}\right.$ $\left.=0.241^{\star}\right)$, so it is necessary to emphasize this trend by testing with enough clones to calculate heritability more accurately. However, given the low genetic control of the content of ascorbic acid, the agronomic management option is viable given the significant positive correlation with the nutrients of magnesium and phosphorus in the soil and negative with aluminum (Abanto et al., 2016). Concomitantly, Guijarro et al. (2017) when studying Diplotaxis erucoides, they found a strong environmental dependence on the content of ascorbic acid in the leaves, the same that was higher in field conditions compared to the greenhouse.

On a larger scale, when we talk about plant selection, it is pertinent to mention the correspondence between variability and environmental conditions. In other words, the varieties with the best performance in one geographic area will not necessarily be the best in another relatively distant region. In camu-camu, observations were made in this regard when comparing relatively distant natural populations (Pinedo et al., 2010). So too, when selecting variants of Carica papaya, Alvarez et al. (2019) found important differences between studied localities, and the need for varietal adaptation to local conditions.

\section{Selections}

During the years 2013 to 2016, individual selections were made according to 16 morphological markers, the most important being:

Plant height (altpla): 140907 (7), TT0812 (5), 141107 (10), BMC1 (5), BMC1 (7), TT0812 (7), 141707 (7), 140907 (1), 141707 (6), 141805 (2).

Average fruit weight (pesfru): Clon64-9, TT0725-4, Clon64-8, Clon61-3, 141001-7, Pc0504-3, 150714-8, I3-2, Clon64-10, TT0725-10.

Fruit yield (yield): TT0725-9, TT0812-5, TT0725-4, Pc0504-5, BMC1-8, Pc0504-6 Clon64-8, Pc0504-8, TT0725-6, TT0812-3.

Ascorbic acid (aciasc) content: Ct0818 (5), Clon64 (8), 04-15-01 (7), Clon61 (3), I-3 (8), NN0323 (3), NY0805 (5), 14 - 02-09 (2), Ct0818 (6), NY0805 (8).

$\%$ of attacked fruits (\% of fruit): BMC1-1, PVC3-8, 11-15-01-2, TT0725-10, Pc05044141101-2, TT0725-2, 150205-3, NY0805-10, 141004- Four.

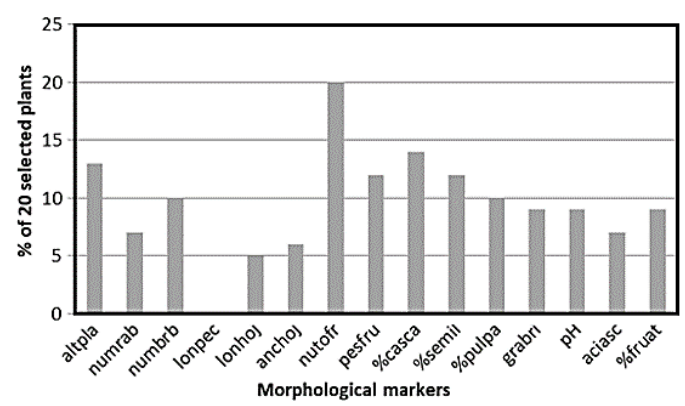

Figure 6. Degree of similarity among the 20 selected individuals with the highest fruit yield compared to the 20 individuals selected by 15 descriptors.

Legend: altpla: plant heigh, numrab: number of basal branches, numbrb: number of basal shoots, lonpec: length of petiole, lonhoj: leaf length, anchoj: leaf width, nutofr: total number of fruits, pesfru: average fruit weight, \%casca: \%fruit peel, \%semil: \%seed, \%pulpa: \%pulp, grabri: brix degree, $\mathrm{pH}: \mathrm{pH}$, aciasc: ascorbic acid content, \%fruat: $\%$ attacked fruits. 
Table 5

Comparison of correlation coefficients and similarity with performance and repetitivity for 16 morphological markers in 43 camu-camu progenies

\begin{tabular}{lccc}
\hline Markers & Correlatión with yield $(r 2)$ & Similarity with yield $(s)$ & Repeti-tivity $(r)$ \\
\hline Altpla & $0.316^{*}$ & 0.65 & 0.44 \\
Numrab & $0.429^{*}$ & 0.35 & 0.36 \\
Numbrb & 0.130 & 0.50 & 0.18 \\
Lonpec & -0.152 & 0.00 & 0.31 \\
Lonhoj & 0.114 & 0.25 & 0.05 \\
Anchoj & $-0.150^{*}$ & 0.30 & 0.06 \\
Nutofr & $0.238^{* *}$ & 1.00 & 0.17 \\
Pesfru & $0.301^{* *}$ & 0.60 & 0.30 \\
\%casca & $-0.183^{* *}$ & 0.70 & 0.18 \\
\%semil & 0.510 & 0.60 & 0.20 \\
\%pulpa & 0.540 & 0.50 & 0.24 \\
grabri & 0.139 & 0.45 & 0.38 \\
pH & -0.207 & 0.45 & 0.15 \\
aciasc & $0.241^{*}$ & 0.35 & 0.08 \\
\%fruat & 0.125 & 0.45 & 0.09 \\
renfru & 1.000 & 1.00 & 0.19 \\
\hline Legend: altpla: plant heigh, numrab: number of basal branches, numbrb: number of basal shoots, lonpec: length of petiole, lonhoj: leaf
\end{tabular}

length, anchoj: leaf width, nutofr: total number of fruits, pesfru: average fruit weight, \%casca: \%fruit peel, \%semil: \%seed, \%pulpa: \%pulp, grabri: brix degree, $\mathrm{pH}: \mathrm{pH}$, aciasc: ascorbic acid content, \%fruat: \% attacked fruits, renfru: yield of fuit.

In the selection for fruit yield of 20 individuals (Table 7), the TT population (TigreTipishca) is present with six individuals (F2) of which three are half-sisters who come from sexual propagation of TT0725 (F1).

For the other markers analyzed, Table 5 summarizes the repetitivity, precision and efficiency coefficients, where the height of the plant stands out due to greater genetic control $(r=0.44)$. The same that in the fourth year reached a value of $\mathrm{rm}=0.611$ and that in the tenth would reach a $r 10=0.887$. Another important descriptor for its potential for indirect selection is petiole length, which reached $\mathrm{rm}=0.475$ in the fourth year. In Figure 5, five markers with greater genetic control are highlighted, of which the most predictive for the possibility of evaluating them in the short term are plant height and petiole length. Likewise, Bardales et al. (2016) found a high contribution of plant height $(75.99 \%)$ to genetic divergence among the populations of Roraima, Brazil.

The interrelationships between fruit yield and the vegetative markers with the highest predictive capacity and the most easily measurable (Table 4) in combination with the repetitivity or heritability indexes will allow choosing priority descriptors as selection criteria. Apparently, the plant height/fruit yield ratio could become one of the first predictive tools for selecting highyielding individuals.

The main product of the present work, as already mentioned, is the selection of highperformance plants with an $r=0.19$ that reached $\mathrm{rm}=0.48$ in the fourth year of evaluation, $69 \%$ precision and an efficiency of 1.59. This test of 43 progenies shows us a different picture of fruit performance compared to previous evaluations of the mate- rial. It is observed that the TT progeny (Tigre-Tipishca) stands out with several halfsisters for fruit yield. The lower productive capacity of the absolute control (T MIX) was confirmed, the origin of which was from a heterogeneous sample of material of unknown origin, which did not show good attributes that confirmed its basic nature in terms of selection.

\section{Conclusions}

Applying the repetitivity analysis for four harvests, a selection was made for each descriptor under study; Regarding fruit production, the Tipishca population of the Tigre river stood out, occupying 5 of the first 10 places of merit. Two naturals recombinant individuals were detected for three important descriptors: fruit yield, fruit weight, and ascorbic acid content from the PutumayoCedro and Tigre-Tipishca rivers.

Regarding the possibilities of indirect selection using heritability and correlation calculations, the descriptors that showed the greatest capacity for genetic control are average fruit weight, brix degree, plant height, number of basal branches and petiole length. Of these, vegetative descriptors are preferable because of their predictive ability before bearing fruit. Of these, the variable height of the plant is considered more appropriate. In addition to the heritability and correlation criteria, the new similarity criterion is proposed.

\section{Acknowledgements}

We express our gratitude to CAPES - Coordenação de Aperfeiçoamento de Pessoal de Nível Superior, Governmental Agency of Brazil and CNP for the scholarship granted to the first author of the research and $\mathrm{CNPq}$ for the productivity grant to researcher Edvan Chagas. Also, to the 
IIAP for supporting, the development of research on camu-camu and the author's doctoral training.

\section{ORCID}

M. Pinedo-Panduro (D) http://orcid.org/0000-0003-2865-6637 E. Alves-Chagas (D) http://orcid.org/0000-0001-8604-7819 E. Paredes-Davila (D) https://orcid.org/0000-0003-3714-3040 C. Abanto-Rodriguez (D) http://orcid.org/0000-0001-7956-5482 R. Bardales-Lozano (D) http://orcid.org/0000-0003-4442-3024 P. Cardoso-Chagas (D) http://orcid.org/0000-0002-3182-9335 V.F. Melo (D) http://orcid.org/0000-0002-7943-9969 D. Del Castillo-Torres $\mathbb{D}^{\mathrm{D}}$ http://orcid.org/0000-0003-0852-5197 N.M. Panduro-Tenazoa (D) http://orcid.org/0000-0003-4498-6644

\section{References}

Abanto, R.C.; Rodríguez, C.; Soregui, G.; et al. 2019. Uso de biofertilizantes en el desarrollo vegetativo $y$ productivo de plantas de camu-camu en Ucayali, Perú. Ceres 66: 108-116.

Abanto, R.C.; Pinedo, P.M.; Alves, Ch.E.; et al. 2016. Relation between the mineral nutrients and the Vitamin C content in camu-camu plants (Myrciaria dubia) cultivated on high soils and flood soils of Ucayali, Peru. Scientia Agropecuaria 7(3): 297-304.

Abanto, R.C.; Pinedo, P.M.; Costa, S.A.T.; et al. 2015a. Fuentes de boro en producción del fruto de camucamu en suelos aluviales de Ucayali. Folia Amazónica 24(1): 33-38.

Abanto, R.C.; Alves, Ch.E.; Paes, A.F.L.; et al. $2015 b$. Genotype and Grafting Techniques Effects on Survival and Growth of Camu Camu Plants. Journal of Agricultural Science 7(6): 160-170.

Almeida, L.F.P. 2014. Avaliação do desenvolvimento inicial de acessos de camu-camu (Myrciaria dubia (Kunth) McVaugh) em diferentes condições edafoclimáticas no estado de Roraima. Tese Doutorado. INPA, Manaus. 80 pp.

Alvarez, J.C.; Álvarez, H.L.; Tapia, V.M. 2019. Selección de plantas de papaya sobresalientes en ambientes comerciales con fines de mejoramiento. Revista Mexicana de Ciencias Agrícolas 23: 303-311.

Bardales, L.R.; Alves, Ch.E.; Smiderle, O.; et al. 2016. Genetic Divergence among Camu-Camu Plant Populations Based on the Initial Characteristics of the Plants Journal of Agricultural Science 8(11): 51. 58.

Braga, R.M.; Cardoso, Ch.P.; Mello, V.R.J.; et al. 2018. Cadeia de produção do camu-camu (Myrciaria dubia (Kunth)McVaugh): O caso das regiões produtoras de Loreto e Ucayali na Amazônia Peruana. Interciencia 43(4): 261-268.

Carias, C.M.; Oliveira, M.; Gravina, G.A.; et al. 2016. Predição de ganhos genéticos via modelos mistos em progênies de café Conilon. Coffee Science 11(1): 39-45.

Diaz, C.C.; López, L.E.; Del Aguila, P.J.; et al. 2015. Almacenamiento de carbono en individuos de camu camu arbustivo [Myrciaria dubia (H.B.K) Mc Vaugh] plantados en el centro experimental San Miguel, Iquitos, Perú Folia Amazónica 24(1): 83-90.

Durand, V.J.; Pinedo, P.M.; Paredes, D.E.; et al. 2017. Methods of pruning and stand-thinning in a floodable camu-camu plot. Journal of applied biology \& biotechnology 5(2): 1-7.

Ferreira, L.T.; Venancio, V.P.; Kawano, T.; et al. 2019. El perfil químico genómico revela el mecanismo antiplasmodial in vitro e in vivo de los polifenoles del acaí (Euterpe oleracea Mart.). ACS omega 4(13): 15628-15635.

Guijarro, R.C.; Rodriguez, B.A.; Prohens, J.; et al. 2017. Influence of the Growing Conditions in the Content of Vitamin C in Diplotaxis erucoides. Universitat Politècnica de València. Bulletin UASVM Horticulture 74(2): 1843-5254.

Maia, C.M.; Almeida, S.A.; Macedo, M.L.; et al. 2016. Heritabilidad, repetibilidad y ganancias genéticas en una población de mejora de cajuízeiro. Revista Árvore 40(4): 715-722.

Mathews, D.J.P.; Yuyama, K.; Revilla, C.J. 2016. Does A Greater Number Of Branches Improve Initial Fruit Production In Camu-Camu? A Test under Different Types of Plantations and Cropping Management. Fruits 71(1): 7

Matias, R.G.P.; Silva, D.F.P.; Miranda, P.M.D.; et al. 2016. Relationship between fruit traits and contents of ascorbic acid and carotenoids in peach. Crop Breeding and Applied Biotechnology 16(4): 348-354.

Mendoza, R.O.; Picón, B.C.; Gonzáles, T.J.; et al. 1989. Informe de la expedición de recolección de germoplasma de camu-camu (Myrciaria dubia) en la Amazonia Peruana. Lima (Perú). Instituto Nacional de Investigación Agraria y Agroindustrial. 19 pp.

Morillo, C.A.; Rodríguez, F.A.; Morillo, C.Y. 2019. Morphological Characterization of Lulo (Solanum quitoense Lam.) in the Municipality for Pachavita, Boyacá. Acta Biol. Colomb. 24(2): 291-298

Oliva, C.C.; Chura, Ch.J. 2010. Selección Genética Computarizada, a partir del Banco de germoplasma Myrciaria dubia (H.B.K.) camu-camu arbustivo Mc Vaugh, de la EE-San Roque-INIA Loreto, Perú. Universidad Nacional Agraria de la Molina- Escuela de Post Grado Mejoramiento Genético de Plantas. 7 pp.

Panduro, T.N.; Huamani, Y.H.; Sanchez, E.M. 2016. Concentration and Extraction of Nutrients and Heavy Metals in Seasonal Biomass and the Harvest of Myrciaria dubia (HBK) in an Entisols of Yarinacocha. Infinitum 6(1): 1-9.

Pinedo, P.M.; Zumba, L.C.; Paredes, D.E.; et al. 2018. Defoliation and Pre-harvest Drop of Camu-Camu Fruits in Floodable Area. Journal of Advances in Agriculture 8(1): 1350-1373.

Pinedo, P.M.; Alves, Ch.E.; Paredes, D.E.; et al. 2017. Selection of Superior Genotypes in 37 Clones of Camu-Camu by Repetitivity Analysis. Journal of Agricultural Science 9(6): 175-187.

Pinedo, P.M.; Bardales, L.R.; Vásquez, B.J.; et al. 2017. Ethological control of Conotrachelus dubiae in camu-camu fruits [Myrciaria dubia (Kunth) H.B.K.]. Journal of Advances in Agriculture 7(4): 1162-1167.

Pinedo, P.M.; Paredes, D.E.; Abanto, R.C.; et al. 2014. Selección temprana de plantas de (Myrciaria dubia H.B.K Mc Vaugh) camu-camu, en un ensayo de progenies de polinización abierta. Instituto de Investigaciones de la Amazonia Peruana. Folia Amazónica 23(1): 39-48.

Pinedo, P.M.; Paredes, D.E.; 2011. Evaluación preliminar de 108 progenies precoces de camu-camu Myrciaria dubia (Myrtaceae) en Loreto, Perú. Instituto de Investigaciones de la Amazonia Peruana. Folia Amazónica 20(1-2): 77-82.

Pinedo, F.S; Imán, C.S.; Pinedo, P.M.; et al. 2011. Clonal trial of five genotypes of camu-camu, Myrciaria dubia (H.B.K) McVaugh, in non-flooded area. African Journal of Plant Science 5(1): 40-46.

Pinedo, P.M. 2013. Correlation and heritability analysis in breeding of camu-camu [Myrciaria dúbia (Kunth) McVaugh]. African Journal of Plant Science 7(2): 61 66.

Pinedo, P.M.; Linares, B.C.; Mendoza, H.; et al. 2004. Plan de Mejoramiento Genético de Camu-Camu. Instituto de Investigaciones de la Amazonia Peruana-IIAP. Iquitos. Perú. 52 pp.

Pires, N.A.; Vilela, R.M.; Dos Santos, G.A.; et al. 2017. Evaluation of different selection indices combining Pilodyn penetration and growth performance in Eucalyptus clones. Crop Breed. Appl. Biotechnol 17(3): 206-213.

Resende, M.D.V. 2002. Genética biométrica e estadística no melhoramento de plantas perenes. Brasilia. EMBRAPA: Informação Tecnológica. 975 pp.

Quijano, J.C. 2020. Caracterización genética en poblaciones cultivadas y silvestres de Pouteria lucuma (Sapotaceae), procedente de la provincia de Otuzco - La Libertad, Perú. Tesis Doctoral. Universidad Nacional de Trujillo. Perú. 83 pp. 
Sánchez, M.E. 2020. El camu-camu (Myrciaria dubia): Nuevas experiencias en el manejo agronómico. Universidad Nacional de Ucayali. 65 pp.

Sánchez, B.E.; García, M.M.; Argüelles, C.J.; et al. 2020. Fruit quality attributes of ten Colombian blackberry (Rubus glaucus Benth.) genotypes. Agronomía Colombiana 38(1): 85-94.

Silva, W.; Gómez, P.; Viera, W.; et al. 2016. Selección de líneas promisorias de naranjilla para mejorar la calidad de la fruta. Revista Científica Ecuatoriana 3: 23-30.

Solis, B.J.; Zamarripa, C.A.; Pecina, Q.V.; et al. 2015. Agronomic evaluation of cocoa hybrids (Theobroma cacao L.) for high-yield selection and field resistance to moniliasis. Mex. Cienc. Agríc 6(1): 71-82.

Smíd, J.; Kalousová, M.; Mandák, B.; et al. 2017. Morphological and genetic diversity of camu-camu [Myrciaria dubia (Kunth) McVaugh] in the Peruvian Amazon. PLOS ONE 12(6): 1-15. 